zählt” (921). Dette synspunkt videreføres ved spørgsmålet om evangeliernes komposition (966-981).

Alt i alt får vi med Vorlesungen zur Hermeneutik und Kritik et sikrere og i vid udstrækning helt nyt grundlag for beskæftigelsen med Schleiermachers hermeneutik.

\title{
Peter Grove
}

\section{Claudia Welz}

Vertrauen und Versuchung. Religion in Philosophy and Theology 51. Tübingen: Mohr Siebeck 2010. 290 s. € 64.

Claudia Welz' habilitationsskrift består af seks temmelig forskellige afhandlinger samlet under overskriften Vertrauen und Versuchung, altså en central teologisk og filosofisk problematik. Den korte "Einführung" fortæller, at det drejer sig om "denkend die Grenzen des Denkens zu erkunden und glaubend die Tiefen des Glaubens zu ergründen” (2), idet målet er "phänomennah die Bedeutung und die Erscheinungsweisen, das Potential und die Grenzen des Vertrauens zu klären” (9). I bestræbelsen på at afdække tillidens fænomenologi er bogen bevidst interdisciplinært anlagt. Der anlægges en såkaldt 'negativistisk' metode, fordi tilliden først viser sin egenart, når den ikke længere er selvfølgelig, eller når den mødes af en komplikation.

Første afhandling (I. Klage und Vertrauen) drøfter Job-fortællingen som udtryk for, hvordan Job trods prøvelserne bevarer tilliden til Gud. Anden afhandling (II. Vertrauen und (Fehl-) Urteil) er mere epistemologisk anlagt og undersøger via Kant og Wittgenstein, om der findes holdbare kriterier til at vurdere, hvornår tillid er mere eller mindre velanbragt. Tredje afhandling (III. Der unbegründbare Grund des Vertrauens und die Ambiguität der Subjektivität) udgør bogens interdisciplinære del. På kun 45 sider gennemgås et udvalg af psykologiske, filosofiske, sociologiske og neuro-biologiske perspektiver på tillid. Her er der også blevet plads til fem sider om Løgstrup. Den fjerde (IV. Gottvertrauen, Glaubensgewissheit und Glaubensprüfung) gør det klart, at tillid for Welz dybest set er "Gottvertrauen". Derfor handler bogen ligeså meget om tro som om tillid. Måske lidt overraskende har Welz her valgt at kaste sig over en økumenisk tekst fra 2008, nemlig Grund und Gegenstand des Glaubens nach römisch-katholischer und evangelisch-lutherischer Lehre, der analyseres grundigt og kompetent. Her bliver der også plads til en drøftelse af Wittgensteins Über Gewissheit og Abrahams ofring af Isak (Gen. 22) læst i lyset af Luther og Kierkegaard. Femte afhandling (V. Glaube, Zweifel, Zwischen-Sein) behandler nyere, religionsfilosofiske forståelser af forholdet mellem tro og tvivl. Overraskende inddrages her et poetisk perspektiv, idet der gives megen plads til den israelske digter, Elazar Benyoëtz' poetiske aforismer. Endelig rummer den korte, sidste afhand- 
ling (VI. Vertrauen und Versprechen) en drøftelse af tilliden som sprogligt fænomen. Løgstrup, Austin og Ricoeur omtales hver på ca. en side, men ellers trækkes der igen på Benyöetz. Bogen afsluttes med et langt 'Ausblick' (235-265), der skal forsøge at samle de mange tråde. Det er samtidig bogens teologisk mest interessante del, bl.a. fordi Welz her placerer sig i tilslutning til Luthers retfærdiggørelsesteologi.

Welz' lange og komplekse undersøgelse af tilliden slutter uden noget resultat eller uden at besvare et klart forskningsspørgsmål. Det nærmeste er følgende citat: "Als Quintessenz des Ganzen sei Folgendes festgehalten: In der Versuchung des Vertrauens zeigt sich ein Doppeltes, und zwar zum einen die Lebensnotwendigkeit wechselseitigen Vertrauens und wiederholter Erweise von Verlässlichkeit und Vertrauenswürdigkeit, zum anderen aber auch die ambivalente Freiheit des Selbst, sich dem Vertrauen bzw. der im Vertrauen liegenden Forderung des Anderen verweigern oder sich der Gabe des Glaubens verschließen zu können, wodurch die Versuchung jedoch keineswegs beendet ist, weil sich der misstrauisch gewordene Mensch in seiner Ablehnung oder gar Verurteilung des verdächtigen Anderen selbst versucht, sofern er mehr wissen zu glaubt, als sich wissen lässt, was ihm dazu verleitet, sich in seinen Vorurteilen zu verfangen und das zu übersehen, was nur das Vertrauen sehen kann” (238f.). Ja, sådan en fin, lang sætning kan man lave på tysk.

Som læser efterlades man med et ambivalent indtryk af bogen, som jo i dette tilfælde er et videnskabeligt svendestykke. På den ene side et fint vidnesbyrd om Welz' imponerende, intellektuelle kapacitet: det hele er meget tysk og mohrsiebecksk, hvilket jo i sig selv er nok til, at man respektfuldt bøjer sig i støvet. På den anden side er der på mindst to områder noget utilfredsstillende ved dette habilitationsskrift, for det indløser ikke, hvad det selv stiller i udsigt: dels en tillidens fænomenologi, dels en interdisciplinær undersøgelse. Jeg har tænkt en del over, hvordan det kan være. Jeg tror, forklaringen skal findes deri, at bogens (og dermed Welz'?) tankeunivers struktureres af et på forhånd fastlagt værdi-hierarki: Øverst er Bibelens Gud som altings garant. Lige under ham - så at sige på ærkeenglenes plads - har vi Luther og Kierkegaard, assisteret af under-englene Jüngel og Dalferth. Længere nede møder vi så en række filosoffer, som man kan diskutere med uden at bringe sin teologi i fare, nemlig Heidegger, Wittgenstein, Ricoeur og Levinas. Og nederst i hierarkiet finder vi så endelig dem, som det vel burde dreje sig om i denne angiveligt interdisciplinære afhandling, altså dem, der har leveret forskellige analyser af tilliden, dvs. Erikson, Løgstrup, Luhmann, m.fl. Men dem gøres der kort proces med. De får en fire-fem sider hver, lige nok til at Welz kan vise, at hun har forstået dem og kan anføre et par kritiske indvendinger. Men sådan arbejder man if. denne anmelder ikke interdisciplinært - og Welz ser da heller ikke ud til at lære noget, hun ikke vidste i forvejen. Midt i al den teologiske alvor og indimellem halv-fromme patos bliver det hele derfor til syvende og sidst et ualvorligt spilfægteri, fordi 
de egentlige svar er teologiske. Og det vil for Welz tilsyneladende sige, at de stort set er givet på forhånd.

Troels Nørager

\section{Matias Møl Dalsgaard}

Det protestantiske selv. Kravet om autenticitet $i$ Kierkegaards tenkning. København: Forlaget Anis 2012. 279 s. Kr. 299.

Denne bog er bemærkelsesværdig på mange måde. Hvem havde fx på forhånd regnet med, at en af de sjoveste teologiske bøger i 2012 ville være en filosofisk ph.d.-afhandling. Nogen må dog have haft det på fornemmelsen, for Mattias Møl Dalsgaards (MMD) bog blev meget mod sædvanen udgivet samme dag som forsvaret. De fleste venter og retter først eventuelle fejl og mangler. Det er ikke sket i her. Derfor staves Augustin på tre forskellige måder i litteraturlisten, Luther citeres på engelsk og Plinius den Ældre finder man gengivet som Pliny the Elder. Sædvanligvis plejer den slags formelle fejl at betyde, at indholdet er lige så sløset, men ikke her. Tværtimod har vi at gøre med et usædvanligt værk. Ganske vist kan også dele af indholdet kritiseres; men den bærende argumentation i bogen er af en sådan karakter, at man gerne bærer over med det meste.

Kierkegaard er nævnt i undertitlen, men det er væsentlig for MMD, at Kierkegaard først og fremmest er en "fremragende eksponent for den lutherske protestantisme" og derfor en velegnet indgangsvinkel til det protestantiske selv, som MMD har i kikkerten. Bogen lægger sig op af den Weber-Taylorske tese om sammenhængen mellem protestantismen og udviklingen af den vestlige kultur, og nøjes i den sammenhæng ikke blot med at påpege, at Weber og Taylor har calvinsk slagside, men forsøger også at levere en del af den nødvendige lutherske ballast til en generel, men nuanceret tese om protestantismens forhold til vestlig modernitet.

Omdrejningspunktet er det krav om selvets autenticitet, som MMD finder i protestantismen og i særlig grad hos Kierkegaard. Det er antagelsen, at protestantismen har spillet en afgørende rolle for den moderne forståelse af selvet. Taylor er her inspirationen. Den ubestemthed, som lutherdommen lægger ind i selvets etiske liv, har if. MMD stor betydning, og er netop overset hos såvel Weber som Taylor (17). Det er tesen - som MMD medgiver i sidste ende ikke kan bevises -, at det sekulariserede selv også er et kristent selv (19f). Fremfor at begive sig ud i umulig bevisførelse, må han i stedet nøjes med at dokumentere det rimelige i tesen.

Bogen er delt i seks kapitler, der udover indledningen tæller kapitler om kravet om fuldstændighed (kap. 2), der først og fremmest drejer sig om bestemmelsen af mennesket som vilje i den tidlige kristendom (primært Augustin), om selvet uden selvhjælp (kap 3), der omhandler det lutherske opgør 